\section{十勝沖地蹑による函館市の地形災害}

\section{瀬川秀良}

函館市の蒙った災害では，海岸段丘上の函館 大学の被害が大きいが，同じ段丘上の他の建物 に全く被害がないから，地形や地質からはこの 被害は裞明できない。その他の地震による災害 はすべて沖皘地，それも海岸の埋立地に限られ ている。海岸砂による埋立地は弱く，砂磁で埋 立てた所は比較的安全であった。

海岸砂で埋立てた所では噴砂が著しい。日本 化学飼料会社では北西一南東方向の亀裂に沿5 て砂が噴き出し，500!に及ぶと推定される。粕 裂と沈降とが函䬼市の沖和地に求ける主要な地 形災害であり，关の分布は図に示した。五稜郭 の石垣名多く破損したが，龟裂の一形式と考之

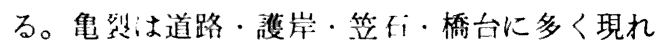
た。亀裂の力向は北西一南東を主とし，これに 直父交るものが次ぐ。砂による埋立地では前述 のごとくこれら亀裂に噴砂が伴なった。

沈降汇はせまい範囲の陥没、仏い範囲の沈下 といらべきものの他に，海岸では海岸側への傾 斜しながら沈临したものがあり，ま心隆起と沈 降とが並存するもの、水平移動を兴った沈降な どボする。

1955 年に埋けてた朝市埋立地では平均く0 $60 \mathrm{~cm}$ の沈下が落ったが，酒岸では長さ 20m， 幅 $4 \mathrm{~m}$ にわたり，1 $\mathrm{m}$ 程度沈下した。闹時に南 西方向への水平移動米㚣った。必下に上り，水 道管心破机、一帯は水びたしになった。5 月 16 日18 時 12 分の津波は満潮と重なり, 平均 海面上 $146 \mathrm{~cm}$ に達し，決壊した海岸堤防から 海水心淮入し，24 棟が地上 $30 \sim 60 \mathrm{~cm}$ 位の深 己に淠水した。朝市埋立地のか的它旅館は $40 \mathrm{~cm}$ 程度傾斜沈下し, 道路と玄関の間が $8^{\circ}$ の 斜面となった。

海岸町の三菱石湖油䐬所では3基のタンクが

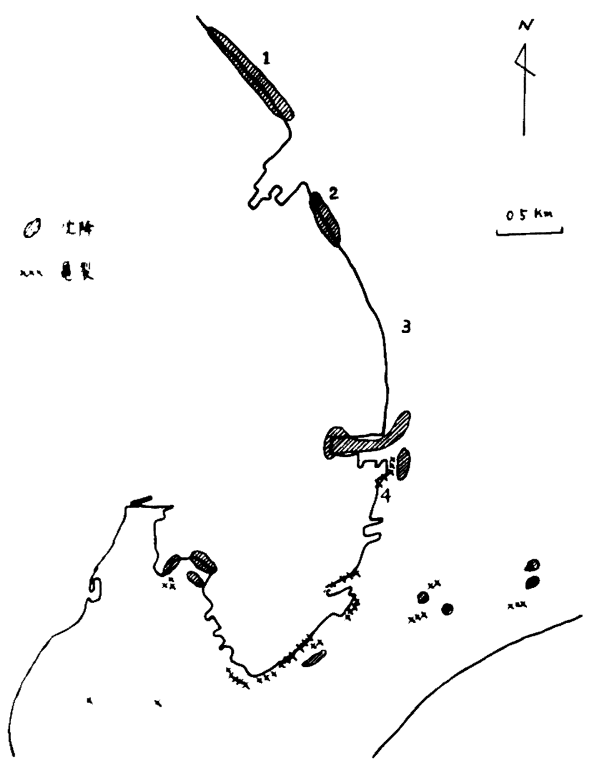

函管市の裂および沈降地域

1 函館フライウッド 2 日本石油

3 日本化学飼料 4 三菱石油

沈下したが, 中央のタンクは東方に $5^{\circ}$ 傾斜し た。日清製粉では $2 \mathrm{t} / \mathrm{m}^{2}$ の重さに小麦粉を積 んでいた倉庫が 80〜 $100 \mathrm{~cm}$ 沈下したが，地下 タンクがく0〜 60cm 隆起した。

末㳂町の地下 $80 \mathrm{~cm}$ のガス管の破損状態を調 べると，初め西方に移動，僅かな沈下，次いで 大きく東方に移動したことが推察される。

埋立地の軟弱地盤においては，重量を支持す る力が地震の時に失われ, 重い構造物が沈下 し, 移動する。朝市埋立地のよ5に大量に水を 含んだ砂の上では建築物が傾斜に沿らて舟のよ 弓に移亜する。軟弱地盤の特殊性として考虑す べきものと思われる。（1968.8. 26 受理）

西村ほか（1968）：十勝地震による地形災害 東北地 理 $20 \quad 15 i \sim 160$

\title{
Damages by the Tokachi-oki Earthquake in Hakodate City Shuryo SEGAWA
}

Damages by the Tokachi-oki Earthquake in Hakodate City were found mainly in the relcaimed land. A remarkable exception was the case of the Hakodate College which was built on the terrace. The four storied concrete building of the college collapsed due to the earthquake, and apparently there was a serious deffect in the construction.

Many cracks and depressions of the ground happened in the reclaimed land, mainly filled-in with sand, which caused the quicksand phenomenon at the time of the Earthquake. 